\title{
Thinking through heterogeneous infrastructure configurations
}

\section{Mary Lawhon}

University of Oklahoma, USA

\section{David Nilsson}

KTH Royal Institute of Technology, Sweden

\section{Jonathan Silver}

University of Sheffield, UK

\section{Henrik Ernstson}

KTH Royal Institute of Technology, Sweden; and The University of Manchester, UK

\section{Shuaib Lwasa}

Makerere University, Uganda

\begin{abstract}
Studies of infrastructure have demonstrated broad differences between Northern and Southern cities, and deconstructed urban theory derived from experiences of the networked urban regions of the Global North. This includes critiques of the universalisation of the historically-culturally produced normative ideal of universal, uniform infrastructure. In this commentary, we first introduce the notion of 'heterogeneous infrastructure configurations' (HICs) which resonates with existing scholarship on Southern urbanism. Second, we argue that thinking through HICs helps us to move beyond technologi$\mathrm{cal}$ and performative accounts of actually existing infrastructures to provide an analytical lens through which to compare different configurations. Our approach enables a clearer analysis of infrastructural artefacts not as individual objects but as parts of geographically spread socio-technological configurations: configurations which might involve many different kinds of technologies, relations, capacities and operations, entailing different risks and power relationships. We use examples from ongoing research on sanitation and waste in Kampala, Uganda - a city in which service delivery is characterised by multiplicity, overlap, disruption and inequality - to demonstrate the kinds of research questions that emerge when thinking through the notion of HICs.
\end{abstract}

\section{Keywords}

infrastructure, provincialising theory, Southern theory, urban political ecology, urban theory

Received February 2017; accepted June 2017

Corresponding author:

Mary Lawhon, Department of Geography and

Environmental Sustainability, I00 East Boyd St. SEC Suite

510, Norman, OK 73019, USA.

Email: marylawhon@gmail.com 


\section{摘要}

基础设施研究证明了南北半球的城市之间有着广泛的差异, 也瓦解了根据北半球城市圈的经验 发展起来的城市理论。以历史和文化为根基，北半球发展了普遍、统一基础设施的标准理想; 基础设施研究批判了这一理想的普世化。在本评论中, 我们首先引入了 “异质基础设施配置” (HIC) 的概念, 这一概念与现有的南半球城市研究相呼应。其次, 我们指出, 按照 HIC 的概念 思考, 有助于我们不仅限于从技术和性能的角度解释实际现存的基础设施, 在此之外提供了比 较不同配置的一个分析框架。按照我们的方式, 就能更清晰地分析基础设施物, 不仅将其作为 个物, 也作为具有地理广度的社会技术配置之一部分: 这些配置可能涉及许多不同类型的技术、 关系、能力和操作，随之而来的是不同的风险和权力关系。我们使用的例子来自对乌干达坎帕 拉市卫生和废弃物的持续研究——这座城市的服务交付以多重性、重叠、分裂和不平等为特征。 我们用这些例子来说明以 HIC 的概念思考时涌现出的研究问题。

\section{关键词}

基础设施、地方化理论、南半球理论、城市政治生态学、城市理论

\section{Introduction}

In the morning, Amaka wakes and goes to the community garden. Nearby there is open space where she relieves herself. She packs, and goes to town to work at her vegetable stall. She uses a nearby private pay toilet that costs 300 shillings (US\$ 0.06). On her way home, it is dark. She goes a little out of her way to stop by her evangelical church, which has a VIP toilet. Her youngest child must be woken in the night and taken right outside, otherwise he wets the bed. There is a nearby municipal toilet: some weeks, it is dirty; some, it is locked. There is also a local private, pay toilet, used occasionally. Two weeks later: Amaka's daughter became pregnant; while the church toilet is still available, social norms prevent its use. Her youngest child now has diarrhoea, making the nightly wakings more frequent and their proximity to the house more problematic. It is the rainy season, and the municipal toilets are filled with mosquitos. There is not enough money for everyone to use the pay toilet all the time.

This description - a composite character from preliminary work in Kampala ${ }^{1}$ - likely resonates with many scholars of urban infrastructure in the Global South: the story of a single woman enrolls a plethora of infrastructures with diverging social, spatial, ecological and economic implications. And it is dynamic: small shifts in health, social relations, weather patterns or state actions all outside her control - reconfigure her daily sanitation needs and patterns.

This story notably diverges with those experiencing conditions of nearly, uniform infrastructure in which water comes through a single network, and is flushed away with little thought of where it goes. Undoubtedly, flushing a toilet is easier and generally safer than the hybrid, partial system described above. And yet, there is a growing recognition of the limited possibilities for achieving universal, uniform networked access to services - what Graham and Marvin (2001) termed the 'modern infrastructure ideal'. Specifically, the social, economic and ecological rationality of modernist systems is being questioned (Coutard and Rutherford, 2015), particularly but not exclusively in Southern contexts where infrastructure disruption is the norm rather than the exception (see Graham, 2010; Silver, 2016).

Critical urban scholars undertaking work in the Global South have responded to this recognition by articulating the geographies and underlying logics of Southern urban infrastructures, focusing on explaining what is there. This growing literature across urban studies has moved accounts away from the 
explanations of why Southern cities fail to achieve the Northern-derived normative notion of what the urban ought to be (Lawhon et al., 2014; Robinson, 2002; Roy, 2009, 2014). Existing accounts have reframed infrastructure as hybrid (Furlong, 2014; Larkin, 2008), incremental (Silver, 2014), post-networked (Coutard and Rutherford, 2011; Monstadt and Schramm 2017), as well as peopled and lived (Graham and McFarlane, 2014; Simone, 2004). Such literatures usefully describe and analyse what is there and how it works - or how and for whom it fails to work. We summarise this literature under the term 'performative' for its description and analysis of 'what is there'. This work has importantly expanded meanings and understandings of infrastructure, showing the myriad of technologies operating across the urban domain.

Building on this collective literature, we first propose the notion of heterogeneous infrastructure configurations (HICs). We argue that this vocabulary conceptually resonates with work across urban studies that seeks to better understand both specific artefacts as well as their relations to particular socio-political urban geographies. Second, we argue that thinking through HICs points us analytically towards important questions for future research and intervention. Specifically, it enables a clearer analysis of infrastructural artefacts not as individual objects but as parts of geographically spread socio-technological configurations: configurations which involve many different technologies, relations, capacities and operations, entailing different risks and power relationships. Such an analysis moves beyond debates over state, community or private ownerships, as well as formal or informal infrastructures, and towards comparative thinking about the conditions of possibility for incremental change. Our approach is not intended to valorise any particular social or technological intervention; ${ }^{2}$ instead, thinking through HICs can contribute to more informed, difficult, politically laden choices, and better enables us to question the extent to which infrastructural changes may open up possibilities for more just and sustainable urban conditions.

\section{The modern infrastructure ideal in the Global South}

The 'modern infrastructure ideal' described by Graham and Marvin (2001) was a widely accepted social and political goal that sought to provide universal, uniform infrastructure globally, and continues to underpin normative prescriptions including in the Global South.

The provision of modern infrastructure in colonies in the Global South tended to adopt similar forms of technology to those used in the Global North. For example, Nilsson (2016) examines the export of water infrastructure to Kampala, including the consideration of different possible technical solutions to Kampala's growing water needs. He argues: 'Once the idea of a modern, European-style water supply and sewerage system had emerged as a real possibility among the experts and administrators in Entebbe (Uganda's colonial administrative capital), no other solution appeared plausible'. However, their provision was limited primarily to the 'European' urban areas (Kooy and Bakker, 2008; Silver, 2016). For instance, Kampala had a nominally comprehensive publicly owned service system for solid waste, sanitation, and water, between c. 1930 and 1968. The colonial system covered the entire European administrated part of Kampala and catered for all inhabitants albeit with racially segregated service levels (Nilsson, 2006). Notably, other urban areas still managed water, waste and sanitation, but through a plethora of socio-technical configurations that provided differentiated alternatives depending on social position 
(class, ethnicity, gender). Importantly, these histories continue to inform contemporary practice in areas outside the modern networks and archipelagos (Bakker, 2003) serviced by the state.

Although the immediate postcolonial era largely coincided with the emergence of the modern environmental movement, and there was a small but vocal contingent of international and local voices calling for African cities to use 'appropriate technology', largescale, centralised model for water, sanitation and waste services was adopted by postcolonial governments with financial and technical support from international partners (Nilsson, 2016; Silver, 2016). This is largely explained through the optimism of the postcolonial era, and a belief that the modern infrastructure ideal was both desirable and achievable. It also contributed to the legitimacy of liberation movements as they became post-independence governments, creating the expectation of a quotidian relationship between citizens and the state (Nilsson, 2016; cf. Scott, 1998), modelling stateformation on European states (Mamdani, 1996). Public funds, often obtained through international loans, were used to extend lowcost service provision via networked services, but the goal of universal provision remained elusive. By the 1980s, it was clear that state budgets could no longer support this vision (in part due to global economic trends and, more specifically, the forced adoption of structural adjustment programmes). African states and their partners largely remain caught in this predicament, with an ideological desire for modern infrastructure and a practical awareness of an inability to achieve universal access to it. The normative ideal of homogeneity and centralism continues to significantly shape the way residents, planners, governments and academics think about infrastructure (Kooy, 2014; Kooy and Bakker, 2008; Monstadt and Schramm, 2017; Nilsson, 2016; Scott, 1998; Silver,
2016). Importantly, it has also curtailed what can be imagined as possible and desirable.

\section{Urban studies beyond the infrastructure ideal}

This variegated and differentiated infrastructural history has resulted in a legacy of nonuniform modes of service provision, and urban regions display the coexistence of centrally planned infrastructures with infrastructure initiated by local entrepreneurs, grassroots social movements, international NGOs, and/or individuals. Researchers have sought to explicate the everyday experiences and logics of so-called 'informal' urban infrastructure, attending to the range of nodes, actors, and connections and disconnections to various forms of so-called 'formal' infrastructure. Such work shows how infrastructures have become layered by multiple and partial infrastructures including different coverage, technologies, operations, logics and ownerships (Anand, 2011; Chattopadhyay, 2012; Graham and McFarlane, 2014; Silver and Marvin, 2017). Literature on Southern urban infrastructure has also called attention to new possibilities for social organising, ownership and power relations both with and outside of the state.

As in the wider literature on infrastructure, the state and the question of privatisation are a focal point for many scholars. However, while most investigations of neoliberal privatisation focus on networked infrastructure, scholars have explicated linkages between a variety of non-networked conduits. Such work problematises the use of the infrastructure ideal as discursive justification for the formalisation of 'informal' infrastructure and the privatisation of state services (Kooy, 2014), and shows even the emergence of non-networked communities in the Global North (Jepson and Brown, 2014). Others have shown that privatisation can provide opportunities for contestation 
and experimentation (Gopakumar, 2014). Literature in this vein works with unsettled notions of the state and its authority; Ranganathan (2014a), for example, shows how 'water mafias' both act outside of the law and are complicit with the state (cf. Swyngedouw, 1995). Such boundary actors form an essential though fraught conduit for urban flows. Work on infrastructure, citizenship and the state forms another key intervention. Meehan's (2014) study of Tijuana demonstrates the flows of state power through water infrastructure. Although similar literature focuses on the spread of networked infrastructure, Meehan usefully includes consideration of 'informal' infrastructures such as barrels and cisterns as conduits outside of state control. Citizens do not always desire or seek to remain outside of this relationship; access to state-provided services can be sought as a means of legitimising urban residence (Anand, 2011; Ranganathan, 2014b).

Social processes that regulate informal infrastructure have also been a key point of scholarly attention. Landlords/slumlords have been shown to be key vested interests in informal settlement upgrades and resettlement schemes, with the power to trouble initiatives; water providers have similarly been shown to oppose state provision of water infrastructure (Swyngedouw, 1995). McFarlane et al. (2014) show how various social processes enable different modes of access to sanitation options. Despite the importance of existing power relations, networked services have also inspired new forms of collective organising and selfbuilt systems that offer various alternatives to formal, networked infrastructure pursued in the absence of large-scale state and market investment (Schouten and Mathenge, 2010). Thus while constructed as a means through which to obtain services, social mobilisation for infrastructure can also generate more widely relevant 'platforms of engagement' (Ernstson et al., 2014), i.e. associational structures that might not initially have been intended for raising collective demands (strictu sensu political demands), but which might well lead to such demands that are grounded in everyday realities (Silver, 2014).

These and other studies have usefully examined social aspects of Southern urban infrastructure. And while attentive to (re)materialising postcolonial studies through attention to bodies and artefacts, we suggest that these studies remain focused on infrastructure as a lens into social, political and symbolic processes. Our intention here is not to criticise these works for their absences; no study can do all things. Instead, we seek to show key trends in order to highlight a gap in this work, which we believe thinking through HICs can help to address.

\section{Heterogeneous infrastructure configurations}

The literature described above has provided a useful indication of the diversity of infrastructure in the Global South, explanations of modes of operation and politics, and a sense of the everyday practices and challenges of urban residents. In what follows, we demonstrate two key interventions. First, we introduce the notion of HIC as a vocabulary that contributes to consolidating contemporary debates without prescribing theoretical approaches. In other words, the vocabulary below is intended to be complementary to how many Southern urban scholars imagine and describe urban infrastructure. Second, we believe that this notion is analytically useful, and that thinking through HICs helps point to gaps in our existing approaches to the study of urban infrastructure specifically in terms of considering the materiality and extensive and variegated geographies of infrastructure and the dynamism of everyday use, including the (albeit constrained) decisionmaking and agency of individuals seeking to navigate the socio-material differences of specific artifacts within HICs. 
We retain the term 'infrastructure', despite its implications of uniformity and material connectivity. While some have sought alternative vocabulary (such as Jaglin (2015, drawing on Olivier de Sardan) who suggests 'delivery' instead of 'infrastructure'), we argue that the term infrastructure has been sufficiently problematised and reconceptualised by Southern urbanists, and usefully retains a degree of legibility. We associate with wider literatures emphasising the socio-material production and maintenance of all technological artefacts, which bridge "an otherwise artificial divide between "the social" and "the technical" (the "seamless web" of technology and society) [to rather] privileging their mutual constitution' (Coutard and Rutherford, 2015). We also agree with scholars who have argued for a wider notion of infrastructure that includes 'people as infrastructure' (Simone, 2004), deeply embedded in social relations as well as acting as part of material conduits (Anand, 2011; Larkin, 2013). With McFarlane and Silver (2017), we thus consider infrastructure to be 'a practice of connecting people and things in socio-material relations that sustain urban life. It is not just a context or a noun, but a verb: social infrastructure is made and held stable through work and changing ways of connecting'.

The term 'heterogeneous' references a number of aspects of the diversity of infrastructure and is intended to explicitly contrast with the uniformity of the modern infrastructure ideal. It differs from the term 'hybrid' which has been used in literature on Southern infrastructure in two ways. Drawing on science and technology studies, this term has first emphasised the social and natural/material components of technology. We agree with this assertion, although prefer the term socio-material for its specificity (see Coutard and Rutherford, 2015). In literature on infrastructure, and specifically Global South urbanism, hybridity has also been used to emphasise the blurring of the formal/informal binary (e.g. Coutard and Rutherford, 2015: 11; Furlong, 2014; Jaglin, 2015). Although scholars in both traditions use the term to blur a binary, we avoid this term because of its etymological dualism and possible conflation with the STS use. Heterogeneous captures not simply the mixing of two (or more) kinds, but that the kinds being mixed are not clear from the outset. We also avoid the term 'alternative' (e.g. Coutard and Rutherford, 2015) because despite the ubiquity of the norm of the infrastructure ideal, informality remains the majority condition. Instead, we adopt the term heterogeneous as a gesture at sociomateriality, a problematisation of the formal/informal (Varley, 2013), as well as the presence of multiple technological artefacts, uses and users (McFarlane et al., 2014; Rheinländer et al., 2010; Truelove, 2011). As Jaglin (2014: 434) argues, '[m] ore than the overlap between legality and illegality, it is their socio-technical diversity that is an essential feature of these urban delivery channels [i.e. infrastructure]'. Heterogeneity also resonates with the notion of 'worlding' within Southern theory (Roy and Ong, 2011), the idea that what emerges 'locally' can have many sources, and it is not simply the result from pressures of colonisation, globalisation or developmentalism but also local innovation.

We adopt the term 'configurations' rather than the more commonly used 'systems' (see Larkin, 2013) to de-centre the often-held assumption of ordered exchanges between different and diverse technologies that act as 'sub-systems'. The notion of 'system' often also compels an external 'observer' to view, analyse and control 'the system'. We also diverge from others using assemblage or actor-networks as it entails a specific theoretical orientation. In the literature on social studies of technology, 'configuration' has at times been used as a rough synonym for 
system. However, in keeping with wider uses (e.g. Geels, 2002; Summerton, 1994), we adopt the term for its close association with the verb reconfigure, to emphasise that infrastructure is dynamic, undergoing continuous change of construction, assembling, repair and maintenance. The act of (re)configuring might be of revolutionary character, but might also be a continuous process of 'small, incremental adaptations over time' (Summerton, 1994: 5). This term has been used in the literature on Southern urbanism, though rarely explained as a terminological or analytical choice (e.g. Coutard and Rutherford, 2015; Jaglin, 2015). Our emphasis with this term is to examine infrastructural artefacts not as individual objects but as parts of geographically spread sociomaterial configurations: configurations which might involve many different kinds of technologies, relations, capacities and operations, entailing different risks and power relationships. A configuration might be thought of as the range of infrastructural options potentially available to a person for everyday use, a point which shifts us from focusing on the system-developed-fromoutside towards situated-users. They shift over time; some might be unavailable at any given moment for various reasons (functionality, finances, social relationships). Key here is not to delimit the boundaries of a configuration (which are, surely, fluid), but the examination of different artifacts in relation to each other and social relations.

\section{The analytical utility of HICs}

Here, using the exemplary dimensions of risk and power in Kampala, Uganda, we point to key questions that emerge from thinking through HICs. We use the example of waste to demonstrate interrelationships between different artefacts and processes, including consideration of the ways in which 'redundancies' redistribute and reduce risk. We use the example of sanitation to point to how interrelationships between different artefacts and their associated social relations enable and constrain possibilities for use, intervention and wider progressive politics.

\section{Analysing risk through HICs}

Heterogeneity of infrastructure has been described in the literature as being present for a number of reasons. For example, Coutard and Rutherford (2015: 13) summarise key arguments in their edited volume as follows: 'overcapacity, duplication and competition ... is tolerated in these contexts by discourses promulgating the environmental benefits of differentiated management of flows and uses of those flows (e.g. potable vs. non-potable water), economic benefits for utilities and users ... respect for heritage of infrastructure ... and embedded ways of obtaining and consuming water'. We argue here for scholarly research into an additional reason rooted in everyday realities, the ways in which heterogeneity differently responds to conditions of precarity.

Centralised infrastructures developed to exhibit close interdependence internally and externally. Such strongly coupled systems (Hughes, 1983; Kaijser, 1999, 2003) are highly vulnerable to disruption, since if one part of the system fails, the performance of the entire system is affected. In contrast, thinking through HICs brings attention to the interrelationships between different components, and the ways in which seeming overcapacity or redundancies impact risk. Rather than considering multiple pathways as 'competing' (Coutard and Rutherford 2015), we ask under what conditions such infrastructure mitigates risk.

In informal settlements such as Namuwongo and Bwaise, large modernistinspired infrastructure networks entail high risk for residents. Even when services have been paid for in advance, at the end of 
the day the consumers may have to make do without them (Heymans et al., 2014). Residents of certain neighbourhoods in Kampala, depending on class, building year, and closeness to major transport routes, may have access to government-provided services, but this does not preclude such households intersecting with the operations of waste pickers: young waste pickers are sometimes hired to take waste from the wealthier households of Muyenga down the hill to the low-lying neighbourhood of Namuwongo (Silver, fieldnotes, 12 March 2015). In a Northern context, waste might well pile up until state services return, but in Kampala, despite spatiotemporal frictions, the variegated structure of solid waste services seems to allow a continuous flow of the waste material.

In Namuwongo there have been limited inroads into state-provided, universal, uniform waste provision for most residents. Instead, myriad innovations and experiments have sought to extract value or at least minimise the harm of waste piling up (Silver, fieldnotes, 12 March 2015). A briquette project established by an NGO takes both organic household waste (e.g. dried fruit peels from cooking) and leftover charcoal dust and transforms these materialities into a low cost energy source, helping energy-poor households while creating income opportunities. Micro-scale businesses have emerged for waste sorting and resale; private companies have an interest in scaling up on some of these enterprises. Waste pickers seek to find some value amongst the rubbish, and children help reduce the volumes by setting and managing small fires. Youth and children sweep the nearby wetlands and neighbourhoods looking for plastics and metals that they collect into large, bulging bags and carry to awaiting dealers who extract further value (Silver, fieldnotes, 12 March 2015).

While such stories are abundant in the wider literature on waste in the Global South, thinking through the notion of HICs points us to the question of whether and under what conditions these alternatives are more adept at responding to conditions of precarity. For example, when city waste collectors do not pick up the waste, actors in HICs often respond by stepping outside of this state-citizen relationship and drawing on other parts of the existing configuration. HICs, we argue, have more redundancies not through design, but through historical emergence - which have resulted in alternative possibilities when things go awry. When individual waste-pickers do not show up at the landfill - whether because they are taking a day off, are ill, transportation was irregular, or were threatened by officials at the landfill - collection in some form or another typically still occurs. ${ }^{3}$ Briquette schemes in Namuwongo are NGO-dependent on shortterm financing that may simply disappear after a few years; in this case, households that divert organic waste to form briquettes may simply stop doing so. Users may purchase a different fuel source for a time before reverting back when the briquettes are again available. Recyclables not diverted may be saved as future capital, traded in different form or with different purpose or simply integrated into other waste streams. In short, when something goes wrong, the waste does not necessarily pile up (for long).

Our argument is not that such systems are without friction and tension, or that this process occurs seamlessly. Instead, we suggest that thinking through HICs pushes us beyond analysing any specific innovation or intervention into seeing the relationships between these different efforts, and the ways in which they complement and conflict with each other. It calls our attention to thinking about ways in which complementarities and fluidity reduces risk in uncertain conditions. More work is certainly needed to understand the diverse kinds of risks, redundancies, and strategies of users participating in such configurations. 


\section{Thinking power through HIC}

Centralised infrastructure, just like modern city building, became a key way of connecting citizens with the state, and extending state power. This process has typically been accompanied not just by increasing the level of standardisation and homogeneity within infrastructure, but what Scott (1998) calls 'state simplification'; the superimposition of a generic or birds-eye view that structures problem-definition with corresponding blanket solutions for local and specific problems. Through the enforcement of common standards, the state or municipal utilities have determined the specifications of plumbing, the pressure and cost of water, the types of in-home electrical appliances, what kind of telephones are compatible, and so on (Blomkvist and Nilsson, 2017). As the state reaches out with service provision, citizens relinquish some resources and power to the central authority. Defining the boundary of who should be 'in' and 'out' of the public service system is a question of political and economic power and central governments have sometimes used infrastructure extension as a means to secure legitimacy and gain political support for and from specific groups (Kooy and Bakker, 2008; Nilsson and Nyanchaga, 2008). As above, this was also one of the (ultimately failed) strategies of post-independence governments (Nilsson, 2016).

In Kampala's many informal settlements, sanitation provision incorporates a plethora of ownerships, users, technological artefacts, usages and temporalities. The lack of central authority over Kampala's varied infrastructure configurations means that they are largely characterised by situated and decentralised power relations, although the presence of Northern NGOs may nest these local power relationships and configurations into the larger and global arena. The recent history of 'flying toilets' - to defecate in a plastic bag and throw it away - has slowly been replaced by efforts by NGOs, entrepreneurs, churches and neighbours in finding new ways to develop service provision (Brown, 2015). For example, in Namuwongo, the NGO 'Hands for Help' built a toilet block with attendant services and charge a few hundred shillings to adults and free entry for children (Silver, fieldnotes, 12 March 2015). One of the evangelical churches along the rail tracks constructed and then opened up some nearby facilities for its congregation to use freely. Neighbours in the densest part of the neighbourhood, Soweto, built a pit latrine wrapped in corrugated iron for privacy and it is used by a number of surrounding households freely but through collective maintenance. A young entrepreneur began with two toilets built with a loan and expanded to four, providing sanitation facilities for nearby businesses, juggling his income with expenses such as the removal of the waste from the storage tank, costing 60,000 shilling, a considerable cost when customers pay only 200 shillings. Across the city, the neighbourhood of Bwaise has been a site in which communal toilet blocks have been built to improve sanitation beyond the involvement of the state as a provider (Silver, fieldnotes, 12 March 2015).

Each of these different ownership strategies has a different social power relationships embedded within it: the provision of services by churches, for example, enrolls participants not just into a relationship with an NGO, but implicitly or explicitly may be accompanied by a set of expectations in terms of moral behaviours and possibility financial support for the church. What happens to users who do not adhere to the doctrine associated with the service provider? What of those whose contributions do not meet expectations? Entrepreneurship too is embedded in social relationships. Users might pay in alternative ways, with services or 'in kind' goods; family members of various degrees of extension might be exempt 
from payment; loans might be made temporarily to certain trusted users. Sanitation services, as has been shown to be more widely true regarding for-profit and non-profit initiatives, are thus socially embedded.

While such social relationships have been studied typically as individual artefacts and interventions, our specific intervention is to argue for thinking through these different sanitation artefacts and initiatives as part of infrastructure configurations. This means undertaking research on specific artefacts and initiatives, but also their relationship with other locally available options. For example, how does having a private, pay toilet proximate to an NGO toilet shape the willingness to pay, and the willingness to participate in religious community? What social codes regulate the use of open space for defecation, and how are these interrelated with other artefacts and interventions? How do existing vested interests shape the willingness to experiment, to diversify service options, and to create new social relationships? And to what extent do these power relations enable or constrain the generation platforms of engagement that could support processes of 'radical incrementalism' and 'recursive empowerment' to change power relations from individual to city-level (Pieterse, 2008)? In short, existing infrastructural power relations shape conditions of possibility: such relations can enable or constrain new opportunities as well as provide a focal point for new social relationships.

The diversity of ownership strategies and the associated social relations for sanitation infrastructures are only hinted on in these examples. Our point is that as an analytical lens HIC brings into the view the sociospatial arrangements that are involved in the deployment of this new infrastructure with social, cultural and power relations between landlords offering the land, community saving schemes, technical support from NGOs, branches of the internationally present Slum
Dwellers Federation and municipal permissions to proceed. As attention is drawn to the actions of slum dwellers and other urban social interests in the making of the city, HICs shows a wider terrain of political possibility. At an even wider scale, these HICs could nurture a wider urban economy, providing both the context for localised designs to emerge, and to be translated, or exported to be used elsewhere, inspiring potentially transformative and more sustainable regional urban futures.

\section{Conclusion}

What does all this mean for Amaka, our composite character introduced in the introduction? It means thinking of toilets not just in terms of their presence or absence, but as dynamic, power-laden socio-material artefacts that are part of a web of relations. Thinking through HICs means thinking not just about the proximity of her house to a single toilet. Instead, it means recognising people and their movements and connectivities as well as conditions of precarity. It means accepting that sometimes Amaka's toilets will not be working, but also that working and not working is not a binary but a multifaceted, constrained decision-making process. It means recognising that toilets are enrolled in dynamic networks of power that shape not just permission to use, or cost of use, but the possibilities for intervention; there are social norms that construct a toilet's usability but that usability is always in relation to what other options exist. Thinking through HICs, thus, is to think about infrastructure from the perspective of residents such as Amaka, who most often represent the majority urban experience; it is also to think about residents such as Amaka as part of dynamic sociomaterial configurations.

Our intention in thinking through the notion of HICs is not to romanticise the situation in informal settlements. Instead, for 
both theoretical and pragmatic reasons, we build on conceptual and performative scholarship that argues for starting from the heterogeneous infrastructure configurations already in operation. Our intent is to call for empirical research on the conditions under which particular socio-technical artefacts work, for whom they work, and what it means for infrastructure to work. This will likely require larger, more coordinated studies than those that dominate the current state of the literature, as detailed examination is needed of multiple, coexisting sociotechnical objects and processes, raising important questions of methodology and possibilities for comparison.

We argue that thinking through HICs enables a clearer analysis of infrastructural artefacts not as individual objects but as parts of geographically spread sociotechnological configurations: configurations which might involve many different kinds of technologies, relations, capacities and operations, entailing different risks and power relationships. Thinking through HICs pushes us beyond analysing any specific innovation or intervention into seeing the relationships between these different efforts, and the ways in which they complement and conflict with each other. Thinking through HICs forefronts questions of trade-offs: determining what to do will still require the adjudication of values. For example, such an understanding can help us see that some systems promote more localised control (which some may find good, others problematic), some are easier to make more ecologically sensitive, some have redundancies which reduce the impact of disruption. The notion of heterogeneous infrastructure configurations is, importantly, not intended to provide a new infrastructure ideal. Instead, it provides a framework through which to make more informed, difficult, politically laden choices.

\section{Funding}

Funding was received from Vetenskapsrådet 2015-03543 for the project entitled HICCUP, Heterogenous Infrastructures of Cities in Uganda Project: Thinking Infrastructure with the South.

\section{Notes}

1. A combination of field-based postgraduate training, site visits and workshops, later noted as 'Silver, fieldnotes'.

2. This may be seen as relinquishing responsibility of the state and the wealthy to provide or subsidise infrastructure; we argue that thinking through HICs enables thinking about how to support the kinds of infrastructure configurations that are responsive to social and political pressures at different scales and by different actors, including but not exclusively the state.

3. Our intention here is not to critique the reasons for precarity - strikes, days off, and so on - but instead to frame them as a core condition.

\section{References}

Anand N (2011) Pressure: The politechnics of water supply in Mumbai. Cultural Anthropology 26(4): 542-564.

Bakker K (2003) Archipelagos and networks: Urbanization and water privatization in the South. The Geographical Journal 169(4): 328-341.

Blomkvist P and Nilsson D (2017) On the need for system alignment in large water infrastructure: Understanding infrastructure dynamics in Nairobi, Kenya. Water Alternatives 10(2): 283-302.

Brown S (2015) Kampala's sanitary regime: Whose toilet is it anyway? In: Graham S and McFarlane C (eds) Infrastructural Lives: Urban Infrastructure in Context. London: Routledge-Earthscan, pp. 153-173.

Chattopadhyay S (2012) Unlearning the City. Infrastructure in a New Optical Field. Minneapolis, MN: University of Minnesota Press.

Coutard O and Rutherford J (2011) The rise of post-networked cities in Europe? Recombining infrastructural, ecological and urban transformations in low carbon transitions. In: Bulkeley H, Castán Broto V, Hodson M, et al. (eds) 
Cities and Low Carbon Transitions. London: Routledge, pp. 107-125.

Coutard O and Rutherford J (eds) (2015) Beyond the Networked City: Infrastructure Reconfigurations and Urban Change in the North and South. Abingdon: Routledge.

Ernstson H, Lawhon M and Duminy J (2014) Conceptual vectors of African urbanism: 'Engaged theory-making' and 'platforms of engagement'. Regional Studies 48(9): 1563-1577.

Furlong K (2014) STS beyond the 'modern infrastructure ideal': Extending theory by engaging with infrastructure challenges in the South. Technology in Society 38: 139-147.

Geels FW (2002) Technological transitions as evolutionary reconfiguration processes: A multi-level perspective and a case-study. Research Policy 31(8): 1257-1274.

Gopakumar G (2014) Experiments and counterexperiments in the urban laboratory of watersupply partnerships in India. International Journal of Urban and Regional Research 38(2): 393-412.

Graham S (ed.) (2010) Disrupted Cities: When Infrastructure Fails. New York: Routledge.

Graham S and McFarlane C (eds) (2014) Infrastructural Lives: Urban Infrastructure in Context. Abingdon: Routledge.

Graham S and Marvin S (2001) Splintering Urbanism: Networked Infrastructures, Technological Mobilities and the Urban Condition. London: Psychology Press.

Heymans C, Eales K and Franceys R (2014) The Limits and Possibilities of Prepaid Water in Urban Africa: Lessons from the Field. Washington, DC: The World Bank Group.

Hughes TP (1983) Networks of Power: Electric supply systems in Western Society, 1880-1930. Baltimore: Johns Hopkins University.

Jaglin S (2014) Rethinking urban heterogeneity. In: Parnell S and Oldfield S (eds) The Routledge Handbook on Cities of the Global South. Abingdon: Routledge, pp. 434-446.

Jaglin S (2015) Is the network challenged by the pragmatic turn in African cities? In: Coutard $\mathrm{O}$ and Rutherford $\mathrm{J}$ (eds) Beyond the Networked City: Infrastructure Reconfigurations and Urban Change in the North and South. Abingdon: Routledge, pp. 182-203.
Jepson W and Brown HL (2014) 'If no gasoline, no water': Privatizing drinking water quality in South Texas colonias. Environment and Planning $A$ 46(5): 1032-1048.

Kaijser A (1999) Striking Bonanza: The establishment of a natural gas regime in the Netherlands. In Coutard O (ed.) The Governance of Large Technical Systems. London: Routledge, pp. 38-57.

Kaijser A (2003) Redirecting infrasystems towards sustainability. In: Biel A, Hansson B and Mårtensson M (eds) Individual and Structural Determinants of Environmental Practice. London: Ashgate Publishing Limited, pp. 152-179.

Kooy M (2014) Developing informality: The production of Jakarta's urban waterscape. Water Alternatives 7(1): 35-53.

Kooy M and Bakker K (2008) Splintered networks: The colonial and contemporary waters of Jakarta. Geoforum 39(6): 1843-1858.

Larkin B (2008) Signal and Noise: Media, Infrastructure, and Urban Culture in Nigeria. Durham, NC: Duke University Press.

Larkin B (2013) The politics and poetics of infrastructure. Annual Review of Anthropology 42: 327-343.

Lawhon M, Ernstson H and Silver J (2014) Provincializing urban political ecology: Towards a situated UPE through African urbanism. Antipode 46(2): 497-516.

McFarlane C and Silver J (2017) Navigating the city: Dialectics of everyday urbanism. Transactions of the Institute of British Geographers 42(3): 458-471.

McFarlane C, Desai R and Graham S (2014) Informal urban sanitation: Everyday life, poverty, and comparison. Annals of the Association of American Geographers 104(5): 989-1011.

Mamdani M (1996) Citizen and Subject: Contemporary Africa and the Legacy of Late Colonialism. Princeton, NJ: Princeton University Press.

Meehan KM (2014) Tool-power: Water infrastructure as wellsprings of state power. Geoforum 57: 215-224.

Monstadt J and Schramm S (2017) Toward the networked city? Translating technological ideals and planning models in water and sanitation systems in Dar Es Salaam. International 
Journal of Urban and Regional Research 41(1): 104-125.

Nilsson D (2006) A heritage of unsustainability? Reviewing the origin of the large-scale water and sanitation system in Kampala, Uganda. Environment and Urbanization 18(2): 369-385.

Nilsson D (2016) The unseeing state: How ideals of modernity have undermined innovation in Africa's urban water systems. NTM Journal of History of Science, Technology and Medicine 24(4): 481-510.

Nilsson D and Nyanchaga EN (2008) Pipes and politics: A century of change and continuity in Kenyan urban water supply. The Journal of Modern African Studies 46(1): 133-158.

Pieterse EA (2008) City Futures: Confronting the Crisis of Urban Development. London, New York: Zed Books.

Ranganathan M (2014a) 'Mafias' in the waterscape: Urban informality and everyday public authority in Bangalore. Water Alternatives 7(1): 89-105.

Ranganathan M (2014b) Paying for pipes, claiming citizenship: Political agency and water reforms at the urban periphery. International Journal of Urban and Regional Research 38(2): 590-608.

Rheinländer T, Samuelsen H, Dalsgaard A, et al. (2010) Hygiene and sanitation among ethnic minorities in Northern Vietnam: Does government promotion match community priorities? Social Science \& Medicine 71(5): 994-1001.

Robinson J (2002) Global and world cities: A view from off the map. International Journal of Urban and Regional Research 26(3): 531-554.

Roy A (2009) The 21st-century metropolis: New geographies of theory. Regional Studies 43(6): 819-830.

Roy A (2014) Slum-free cities of the Asian century: Postcolonial government and the project of inclusive growth. Singapore Journal of Tropical Geography 35(1): 136-150.

Roy A and Ong A (eds) (2011) Worlding Cities: Asian Experiments and the Art of Being Global. Vol. 42. Oxford, UK: Wiley-Blackwell.

Schouten MAC and Mathenge RW (2010) Communal sanitation alternatives for slums: A case study of Kibera, Kenya. Physics and Chemistry of the Earth, Parts A/B/C 35(13): 815-822.

Scott JC (1998) Seeing Like a State: How Certain Schemes to Improve the Human Condition have Failed. New Haven, CT: Yale University Press.

Silver J (2014) Incremental infrastructures: Material improvisation and social collaboration across post-colonial Accra. Urban Geography 35(6): 788-804.

Silver J (2016) Disrupted infrastructures: An urban political ecology of interrupted electricity in Accra. International Journal of Urban and Regional Research 39(5): 984-1003.

Silver J and Marvin S (2017) Powering subSaharan Africa's urban revolution: An energy transitions approach. Urban Studies 54(4): 847-861.

Simone A (2004) People as infrastructure: Intersecting fragments in Johannesburg. Public Culture 16(3): 407-429.

Summerton J (1994) Introductory essay: The systems approach to technological change. In: Summerton J (ed.) Changing Large Technical Systems. Boulder, CO: Westview Press, pp. 1-21.

Swyngedouw E (1995) The contradictions of urban water provision: A study of Guayaquil, Ecuador. Third World Planning Review 17(4): 387-405.

Truelove Y (2011) (Re-)Conceptualizing water inequality in Delhi, India through a feminist political ecology framework. Geoforum 42(2): 143-152. 